\title{
THALLIUM IN COLOR TATTOO INKS: RISK ASSOCIATED WITH TATTOOING
}

\author{
Bożena Karbowska, Tomasz Rębiś, Joanna Zembrzuska, Katarzyna Nadolska \\ Poznan University of Technology, Poznań, Poland \\ Institute of Chemistry and Technical Electrochemistry
}

\begin{abstract}
Background: Allergic reactions to metals and metal salts used in tattoo pigments occur surprisingly frequently. For this reason, this study focused on the determination of thallium ( $\mathrm{Tl}$ ) in the samples of color tattoo inks. These inks are commonly used in tattooing processes worldwide. Material and Methods: The samples were analyzed with the use of differential pulse anodic stripping voltammetry. The stripping anodic peak current of Tl was linear over its concentration range of $0.5-6.0 \mu \mathrm{g} / \mathrm{l}$, which corresponds to $2.45 \times 10^{-9}-2.94 \times 10^{-8} \mathrm{M}$. The determined value of the limit of detection (LOD) was equal to $0.149 \mu \mathrm{g} / \mathrm{l}\left(7.29 \times 10^{-10} \mathrm{M}\right)$. Results: The obtained results revealed a wide range of Tl contents in tattoo inks, i.e., $0.0029-0.4275 \mu \mathrm{g} / \mathrm{g}$. The content of this metal varied substantially depending on the pigment used in tattoo inks. Conclusions: Thallium was identified and determined in all tested samples. Its content depends on the country of origin but it does not depend directly on the color. The lowest content of Tl was found in the pink ink and the highest in the violet ink (from Israel), and a similar content was also found in the yellow ink (from Israel). The use of colored inks in larger quantities (a dense pattern and a larger surface area covered) may potentially pose a health risk. The danger of Tl poisoning from tattooing depends on the type of the ink (color) and its origin. As Tl is not considered a micronutrient, introducing such a $\mathrm{Tl}$ content into the body may be associated with a potentially harmful accumulation of this metal in body organs, causing various types of ailments and toxic effects primarily on the nervous, skeletal and circulatory systems. The obtained results suggest that tattooists may be exposed to the toxic effects of $\mathrm{Tl}$ in tattoo inks. The analytical data presented in the paper may constitute the basis for determining the acceptable limits of toxic Tl contents in tattoo inks. Med Pr. 2020; 71(4):405-11
\end{abstract}

Key words: human toxicity, dermal exposure, thallium, potential health risk, DPASV, tattoo ink

Corresponding author: Bożena Karbowska, Poznan University of Technology, Institute of Chemistry and Technical Electrochemistry, Berdychowo 4, 60-965 Poznań, Poland, e-mail: bozena.karbowska@put.poznan.pl

Received: 20 September 2019, accepted: 7 February 2020

\section{INTRODUCTION}

The practice of introducing a permanent colored pattern under the skin has occurred globally and was already common in antiquity. Nowadays, tattooing has gained more social recognition and has become very popular around the world, with millions of people having black or colored tattoos. In Europe, the number of tattooed people is estimated at approx. 100 million $[1,2]$.

Nowadays, a body decorated with tattoos ceases to amaze and shock. More and more companies also produce tattoo inks, the composition of which is very complex, and both tattooists and tattoo-makers are not fully aware of what is permanently introduced under the skin surface. Tattoos most likely represent one of the most extensive exposures of humans to chemical substances and various particles at the micro- and nano-scale [2].

Although tattoo inks are products injected into the skin, they are not classified as medicines or cosmetics. However, the injected ink remains under the skin permanently; thus, the body is exposed directly to its components, including very toxic heavy metals.

Some of the pigments remaining in the dermis give the skin a specific color, while some part of the injected pigment is removed from the skin via the lymphatic system. Consequently, the pigments are in direct contact with the skin tissue and the lymphatic system, and may be further accumulated in the lymph nodes or other organs [3]. The potential human health hazards asso- 
ciated with exposure to tattoo pigments are presented in Figure 1.

Tattoo inks contain many dyes to obtain a specific color, as well as other chemicals, including hydrocarbons and phthalates, which have carcinogenic properties and exhibit a detrimental effect on the hormonal balance [4]. Tattoo pigments are colorful nano- and microparticles which are practically insoluble and are permanently introduced into the dermis by the tattooist [5].

The composition of tattoo pigments, depending on the color, can be presented as follows [6]:

- black inks contain various types of hydrocarbons (petroleum) - most of them are carcinogenic - and may also consist of nickel, iron, carbon (soot or ash); yellow inks contain traces of cadmium sulphite, $\mathrm{PbCrO}_{4}$ (often mixed with $\mathrm{PbS}$ );

- orange inks consist mainly of cadmium and azo dyes; - red inks are the most dangerous dyes for human health. Among iron and cadmium salts, they may also contain mercury or cyanides;

green inks usually contain cobalt, chromium, aluminium, copper, ferrocyanides and ferricyanides;

violet inks mainly contain aluminium, manganese and also azo compounds;

- brown inks consist of iron compounds and azo additives;

white inks contain lead, zinc, titanium and barium sulphate.

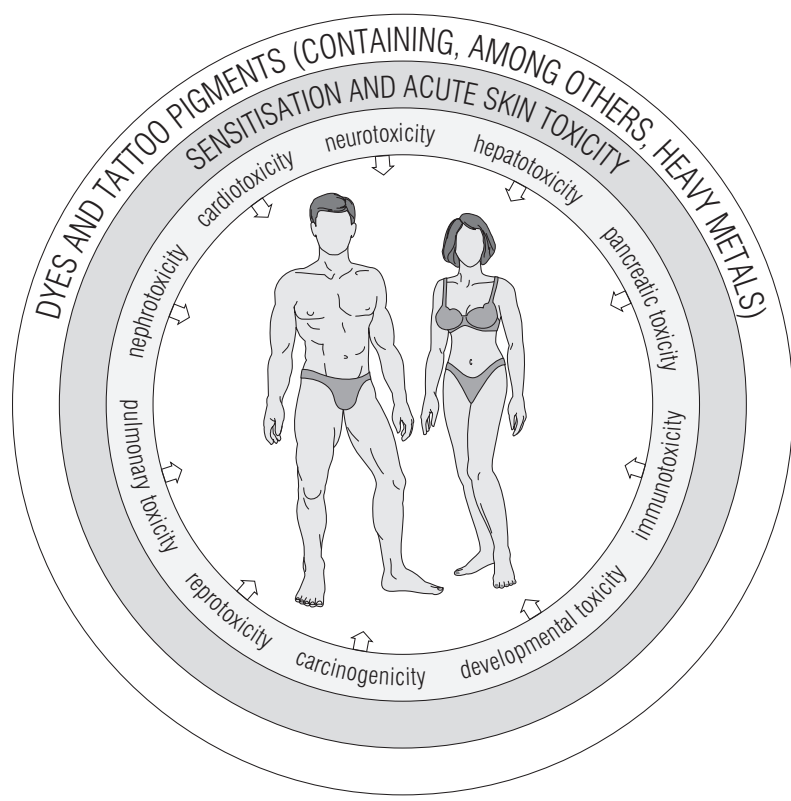

Figure 1. Schematic representation of the potential human health hazards associated with exposure to tattoo pigments
To the best of the authors' knowledge, there is a lack of precise rules which define the raw materials that are used for the production of pigments. Moreover, data regarding toxicity tests of tattoo inks are also limited. However, there is a growing body of research reporting a number of heavy metals contained in tattoo inks. The motivation of this work is that the allergic reactions to metals and metal salts used in tattooing pigments have become surprisingly frequent.

The mechanism of $\mathrm{Tl}$ toxicity involves a disorder of enzyme activity and metabolic processes [7,8]. Symptoms of $\mathrm{Tl}$ poisoning typically include hair loss, ulcers, internal bleeding, myocardial injury, alopecia, polyneuropathy, insomnia, paralysis, the loss of weight and, eventually, death [9].

The aim of this study was to examine the content of $\mathrm{Tl}$ in several types of tattoo inks in terms of the health risks borne by tattooed persons. The samples were analyzed with the use of differential pulse anodic stripping voltammetry (DPASV). The main benefits of this method include low detection and quantification limits, low costs and simplicity.

\section{MATERIAL AND METHODS}

\section{Sample collection, treatment and analysis}

A total of 45 samples of 5 different imported tattoo pigments were obtained from a tattoo ink supplier in Poland. Green and violet inks came from an Italian company, whereas pink, yellow and violet inks came from an Israeli company. All these colors were supplied as commercial liquids.

\section{Total decomposition}

A tattoo ink sample (approx. $0.25 \mathrm{~g}$ ) was placed in a tapered Teflon beaker and treated with $73 \%$ hydrofluoric acid $(2 \mathrm{ml})$. The sample was then heated for $2 \mathrm{~h}$ on a graphite heater until complete evaporation, and then further digested with $\mathrm{HNO}_{3}(65 \%), \mathrm{HClO}_{4}$ (70\%), $\mathrm{H}_{2} \mathrm{SO}_{4}$ (98\%) and $\mathrm{H}_{2} \mathrm{O}_{2}(30 \%)(3: 2: 1: 1)[10,11]$. All chemical reactants were obtained from Sigma-Aldrich (Poland).

Finally, after evaporation, the dry residue was dissolved for $2 \mathrm{~h}$ in $1 \mathrm{ml}$ of nitric acid (the beaker was covered with a watch glass). The samples were digested in 3 replicates in each test and reagent blanks were run.

The dissolved sample was transferred into a $25 \mathrm{ml}$ volumetric flask with ascorbic acid (1 M; $2.5 \mathrm{ml})$ and EDTA $(0.2 \mathrm{M} ; 6.25 \mathrm{ml})$. The $\mathrm{pH}$ was adjusted to $4.5(25 \%$ ammonia). Then, it was transferred into a flask $(25 \mathrm{ml})$ 
and supplemented with water. This solution was used to determine the total content of $\mathrm{Tl}$ in the tattoo inks with DPASV, using a mercury film electrode based on a glassy carbon disc (GCE/Hg(MFE)). Differences between the mean concentration of $\mathrm{Tl}$ in particular color inks were determined with ANOVA and the post-hoc Tukey test.

\section{Determination of $\mathrm{Tl}$}

The determination procedure was conducted with the use of a $\mu$ Autolab electrochemical analyzer from Ecochemie (Utrecht, Netherlands), consisting of a typical 3 -electrode cell. The working electrode used in the voltammetry measurements was a mercury film electrode deposited on a glassy carbon $\operatorname{disc}(\mathrm{d}=3 \mathrm{~mm})$. A silver/silver chloride electrode $(\mathrm{Ag} / \mathrm{AgCl}, 3 \mathrm{M} \mathrm{KCl})$ was the reference electrode, and a platinum wire served as the auxiliary electrode. The system worked under the following conditions: a differential pulse amplitude of $50 \mathrm{mV}$, a step potential of $2 \mathrm{mV}$, pre-concentration at $-1.2 \mathrm{~V}$ vs. an $\mathrm{Ag} / \mathrm{AgCl}$ mercury film deposition period of $600 \mathrm{~s}$, using a $0.05 \mathrm{mM}$ mercury(II) solution of nitrate and $0.1 \mathrm{M}$ potassium nitrate.

All the solutions were prepared in water by reverse osmosis in a Demiwa 5 rosa system (Watek, Czech Republic). Each sample was degassed by a nitrogen gas flow for $600 \mathrm{~s}$. The pre-concentration of $\mathrm{Tl}$ in the samples was carried out over 300-900 s, depending on the $\mathrm{Tl}$ concentration, and EDTA $(0.05 \mathrm{M})$ was used as the supporting electrolyte.

The concentration of $\mathrm{Tl}$ in the samples was estimated with the standard addition method using a certified reference material. The standard soil sample NCS DC 73382 , certified for the total content of $\mathrm{Tl}(1.0 \pm 0.2 \mu \mathrm{g} / \mathrm{g})$, was used as the reference material (Chinese National Standard Reference Materials, Beijing).

\section{RESULTS}

The obtained results revealed a wide range of $\mathrm{Tl}$ contents in tattoo inks, i.e., $0.0029-0.4275 \mu \mathrm{g} / \mathrm{g}$, and the content of this metal varied substantially depending on the pigment used in tattoo inks.

During the successive additions of different contents of $\mathrm{Tl}^{+}$to $10 \mathrm{~mL}$ of EDTA, a well-defined response was obtained, indicating good electroanalytical properties of the mercury film electrode deposited on the GCE electrode. A linear relationship between the anodic current and the $\mathrm{Tl}$ concentration was observed over the range of $0.5-6.0 \mu \mathrm{g} / \mathrm{L}$, which corresponds to $2.45 \times 10^{-9}-2.9410^{-8} \mathrm{M}$ (Figure 2). The calibration curve was obtained by fit- ting the equation: $\mathrm{y}=58.263 \mathrm{x}-7.725$ with a correlation coefficient $\left(\mathrm{R}^{2}\right)$ of 0.9974 . The limit of detection (LOD) was calculated according to the following formula: $\mathrm{LOD}=(\kappa \times \mathrm{SDa}) / \mathrm{b}$, where $\kappa$ is 3.3 and $\mathrm{SDa}$ is the standard deviation of the intercept, and $\mathrm{b}$ is the slope. The determined value of LOD was $0.149 \mu \mathrm{g} / \mathrm{L}\left(7.29 \times 10^{-10} \mathrm{M}\right)$.

For $\mathrm{Tl}$ determination, the standard addition method previously described by Karbowska et al. [12] was adopted with slight modifications. $\mathrm{Tl}$ pre-concentration was carried out at a potential of $-1.2 \mathrm{~V}$ vs. $\mathrm{Ag} / \mathrm{AgCl}$ and the deposition time of $300 \mathrm{~s}$. Also, EDTA (0.05 M) was used as the supporting electrolyte. Lead and $\mathrm{Tl}$ exhibit similar electrochemical properties. As a result, the overlapping voltammetric signals from both metals are usually observed in systems containing no complexing electrolytes [13]. To avoid such a problem, EDTA can be added. The complex of EDTA with $\mathrm{Pb}^{2+}$ is very stable and hinders the reduction of $\mathrm{Pb}^{2+}$ to the metallic state, thus minimizing the interference of this ion. Due to the use of EDTA supporting electrolyte, the method tolerates a 1000-fold excess of lead [14].

A preliminary voltammetric study allowed for the selection of $-1.2 \mathrm{~V}$ as the optimum potential for the present investigation. The concentration of $\mathrm{Tl}$ in the sam-

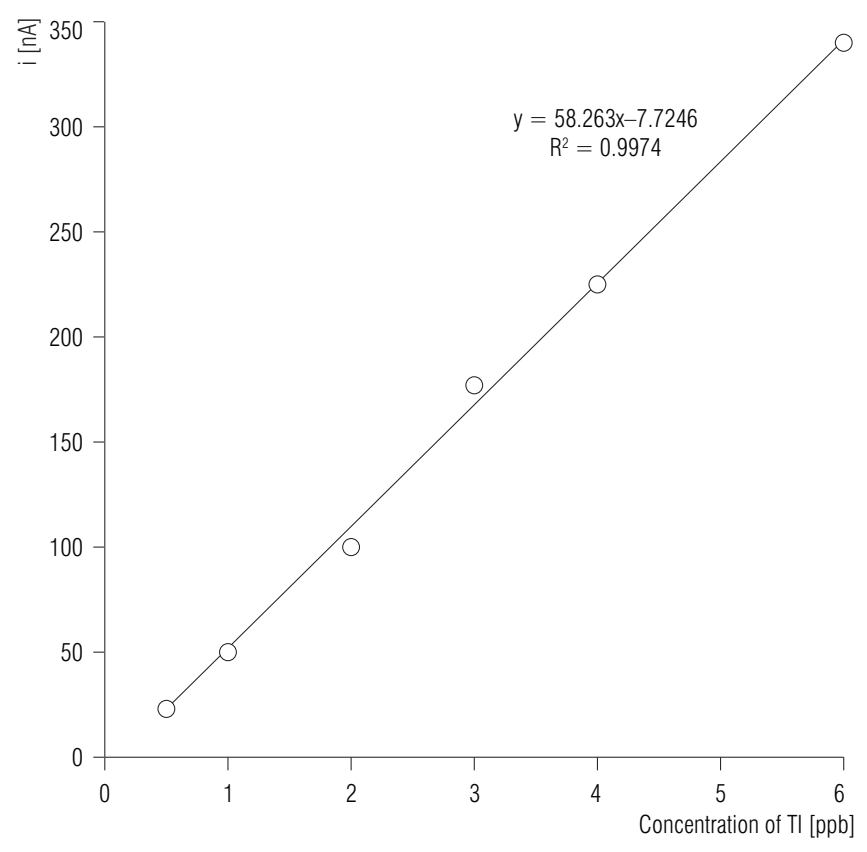

EDTA - disodium ethylenediaminetetraacetic acid, GCE/Hg(MFE) mercury film electrode deposited on a glassy carbon disc $(\mathrm{d}=3 \mathrm{~mm})$, TI - thallium.

Figure 2. Calibration curve obtained for the GCE/Hg(MFE) electrode in EDTA after addition of $0.5,1,2,3,4,6 \mu \mathrm{g} / \mathrm{l} \mathrm{Tl+}$, $300 \mathrm{~s}$ of pre-concentration at $-1.2 \mathrm{~V}$ vs. $\mathrm{Ag} / \mathrm{AgCl}$, a pulse amplitude of $50 \mathrm{mV}$, a step potential of $2 \mathrm{mV}$ 
ples was estimated on the basis of several standard additions (Figure 3). In order to determine standard deviation (SD), each sample was measured 3 times (Figure 3). Control measurements were performed together with each series of experiments. As many as 9 independent trials were conducted for the reference material (the standard soil sample NCS DC 73382) in order to determine the $\mathrm{Tl}$ content. The average content of $\mathrm{Tl}$ was at $0.949 \pm 0.0967 \mu \mathrm{g} / \mathrm{g}$ (min. 0.821 and $\max 1.102 \mu \mathrm{g} / \mathrm{g}$ ).

The obtained results for the $\mathrm{Tl}$ content in tattoo inks are presented in Table 1 . The results show a great variation of heavy metal concentrations in the samples. The max- imum concentration of $\mathrm{Tl}$ was observed in the violet ink (from Israel), with an average value of $0.4275 \mu \mathrm{g} / \mathrm{g} \mathrm{Tl}$. Concerns have also been raised as regards the amount of $\mathrm{Tl}$ that can be introduced with the yellow ink (from Israel) into the human body (an average value of $0.4250 \mu \mathrm{g} / \mathrm{g}$ ). In the pink ink, the content of Tl was the lowest (with an average value of $0.0029 \mu \mathrm{g} / \mathrm{g}$ ).

Such metal concentrations in tattoo inks can be associated with potentially harmful effects. The use of colored inks in large quantities (a more dense pattern and the surface of the coated body) may be hazardous to human health. Actually, Tl rapidly enters the blood stream

Table 1. Thallium concentrations in tattoo inks (in total, 45 samples of 5 different imported tattoo pigments were obtained from a tattoo ink supplier in Poland)

\begin{tabular}{|c|c|c|c|c|c|}
\hline \multirow[b]{2}{*}{$\begin{array}{l}\text { Tattoo ink color } \\
\quad \text { (origin) }\end{array}$} & \multicolumn{5}{|c|}{ Thallium content } \\
\hline & $\begin{array}{c}\mathrm{Me} \\
{[\mu \mathrm{g} / \mathrm{g}]}\end{array}$ & $\begin{array}{c}\min .-\max / \\
\text { interquartile range } \\
{[\mu \mathrm{g} / \mathrm{g}]}\end{array}$ & $\begin{array}{c}\mathrm{M} \\
{[\mu \mathrm{g} / \mathrm{g}]}\end{array}$ & $\begin{array}{c}\mathrm{SD} \\
{[\mu \mathrm{g} / \mathrm{g}]}\end{array}$ & $\begin{array}{l}\text { RSD } \\
{[\%]}\end{array}$ \\
\hline Yellow (Israel) & 0.4250 & $0.330-0.500 / 0.1700$ & 0.4300 & 0.06064 & 14.268 \\
\hline Pink (Israel) & 0.0029 & $0.0025-0.0033 / 0.0008$ & 0.0028 & 0.00026 & 9.123 \\
\hline Violet (Italy) & 0.0210 & $0.0170-0.0250 / 0.0080$ & 0.0200 & 0.00239 & 11.380 \\
\hline Violet (Israel) & 0.4275 & $0.4200-0.4540 / 0.0340$ & 0.4250 & 0.01040 & 2.433 \\
\hline
\end{tabular}

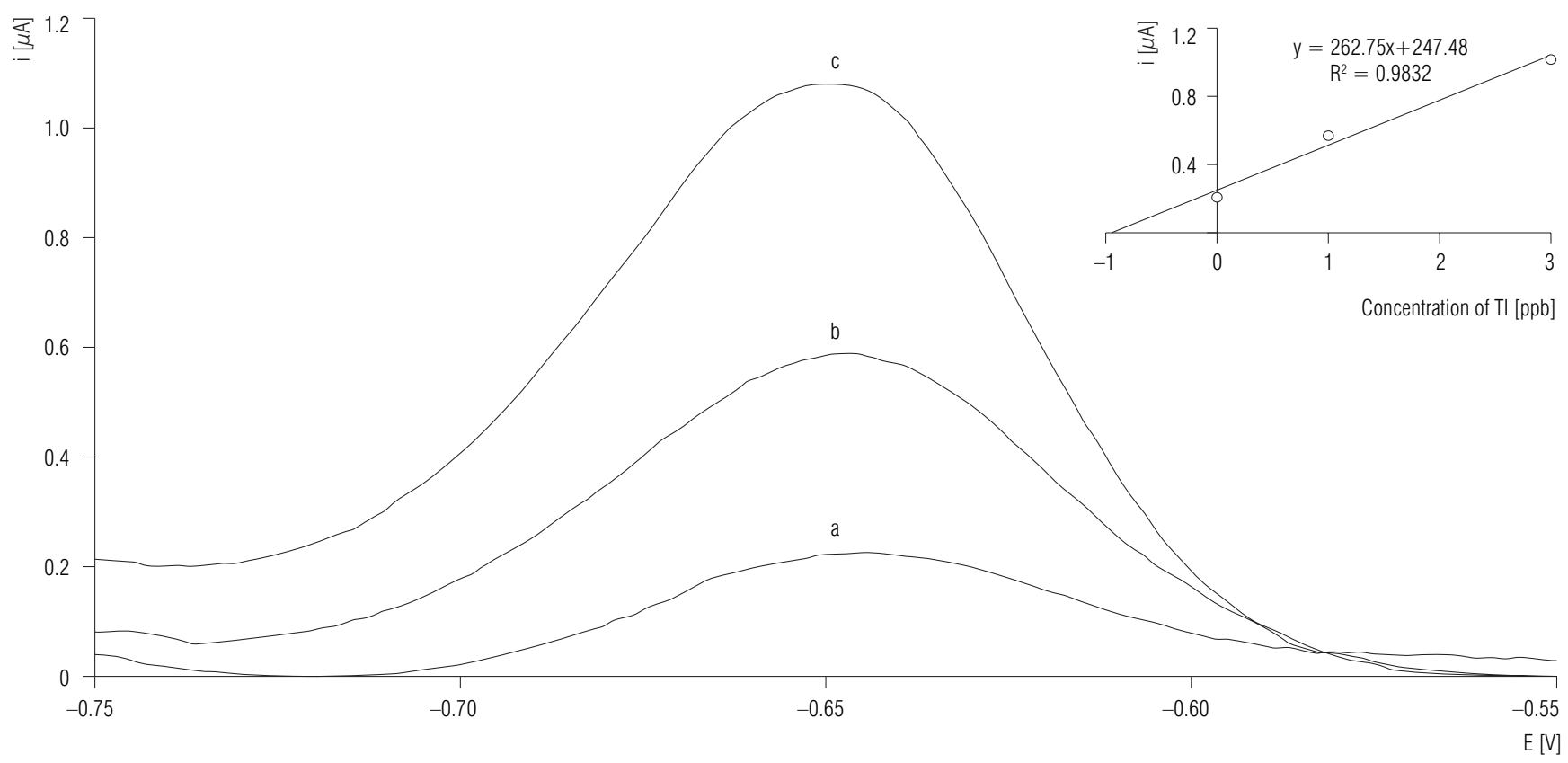

The supporting electrolyte was $0.05 \mathrm{M}$ EDTA $(\mathrm{pH}=4.5)$. Pre-concentration potential of $-1.2 \mathrm{~V}$ vs. Ag/AgCl, pre-concentration time of $300 \mathrm{~s}$, pulse amplitude of $50 \mathrm{mV}$, step potential of $2 \mathrm{mV}$.

Figure 3. Voltammetric curve for the tattoo ink sample and for a) the ink sample with sequential standard addition b) 1ppb Tl, c) $3 \mathrm{ppb} \mathrm{Tl}$ 
and is transported across the whole body, which leads to its accumulation in bones, kidneys and the nervous system. The type and severity of the observed effects are generally correlated with the dose concentration [15].

It should be emphasized that the effects of a permanent exposure to $\mathrm{Tl}$, even at low levels, are not fully understood.

\section{DISCUSSION}

The research carried out by the authors revealed a surprisingly wide range of $\mathrm{Tl}$ contents in tattoo inks, i.e., 0.0029 $0.4275 \mu \mathrm{g} / \mathrm{g}$ depending on the origin and color of the ink. This may cause a serious problem because $\mathrm{Tl}$ salts are currently considered to be one of the most toxic compounds [15]. In order to prevent $\mathrm{Tl}$ poisoning, its content must not exceed the environmentally safe limits which are: $2 \mu \mathrm{g} / \mathrm{l}$ for drinking water, $0.008-1.0 \mu \mathrm{g} / \mathrm{g}$ for land plants, $0.03-0.3 \mu \mathrm{g} / \mathrm{g}$ for edible plants, and $2 \mu \mathrm{g} /$ day for the average daily intake [16-18].

The maximum admissible content of $\mathrm{Tl}$ in tattoo inks has not been determined yet. For other heavy metals such as lead, cadmium, chromium and arsenic, the allowable content was determined by the U.S. Environmental Protection Agency (USEPA) in 2013 [18]. Therefore, estimating the safety assessment of tattoo inks is a complex problem, especially due to the fact that they are more invasive to the body than cosmetics, which are used only on the skin and can be easily removed during washing.

Tattoo inks were previously analyzed mainly using spectroscopic methods (ICP-MS) to detect heavy metals such as cadmium, lead, mercury, chromium, copper, cobalt and nickel. The distributions of metals found in various tattoo inks, sorted by color [19], together with the determined $\mathrm{Tl}$ content in the samples tested in this work, are summarized in Figure 4. Green inks were found to contain high concentrations of chromium, copper, lead, nickel and cadmium, as well as cobalt. Violet inks contain similarly substantial amounts of chromium, copper, lead, nickel and cadmium. High concentrations of cadmium and chromium were found in pink inks [19]. Lead is a known toxin that can cause kidney failure, hypertension, neurological disorders, birth defects and liver damage. In tattoo pigments, lead is present in the form of lead chromate and was observed in bright green and yellow inks. Chromium is known to cause damage to the central nervous system and nickel is an allergen to approximately $20 \%$ of people, and can cause skin sensitivity and rashes. The presence of copper in high concentrations in tattoo pigments $(\max 22.04 \mu \mathrm{g} / \mathrm{g})$ is most likely associated with copper phthalocyanine blue $\mathrm{BN}$, and phthalocyanine green ink pigments that have been used in tattoos for almost 100 years [20].

Body tattooing can be an important risk factor for human health, and it is all the more dangerous because mostly young people get tattooed. It is worth emphasizing that a tattoo will remain for life or for many years. In order to determine the exposure in the form of a systemic dose, expressed as $\mathrm{mg} / \mathrm{kg}$ per day, it is necessary to know how much of the substance deposited in the tattooed skin area, following tattooing, is subsequently absorbed, i.e., to know the percentage of the deposited substance that is transported from the tattooed skin area to the tissues and organs in the body via the blood circulation and/or the lymphatic system [21]. It is worth noting that tattoo inks are not covered by legislation on cosmetic products or on medicine.

\section{CONCLUSIONS}

Thallium was identified and determined in all tested samples. Its content ranged 0.0029-0.4275 $\mu \mathrm{g} / \mathrm{g}$. Generally, its content depends on the country of origin but it does not depend directly on the ink color. The lowest content of $\mathrm{Tl}$ was found in the pink ink and the highest in the violet ink (from Israel), and a similar content was also found in the yellow ink (from Israel).

The use of colored inks in larger quantities (a dense pattern and a larger surface area covered) may potentially pose a health risk. The danger of $\mathrm{Tl}$ poisoning from tattooing depends on the type of the ink (color) and its origin. As $\mathrm{Tl}$ is not considered a micronutrient, introducing such a $\mathrm{Tl}$ content into the body may be associated with a potentially harmful accumulation of this metal in body organs, causing various types of ailments and toxic effects primarily on the nervous, skeletal and circulatory systems. The introduction of certain contents of various chemical compounds, including toxic heavy metals which form part of the pigment used in the tattooing process, into the body (under the skin) can be an important risk factor for human health. The obtained results suggest that tattooists may be exposed to the toxic effects of Tl present in tattoo inks.

The health effect assessment includes local effects in the skin as well as systemic effects, i.e., the effects that occur in tissues and body organs after the substance is absorbed from the tattooed skin area [21]. Unlike cosmetics, tattoo inks are not officially controlled. Although the industry needs to comply with certain reg- 


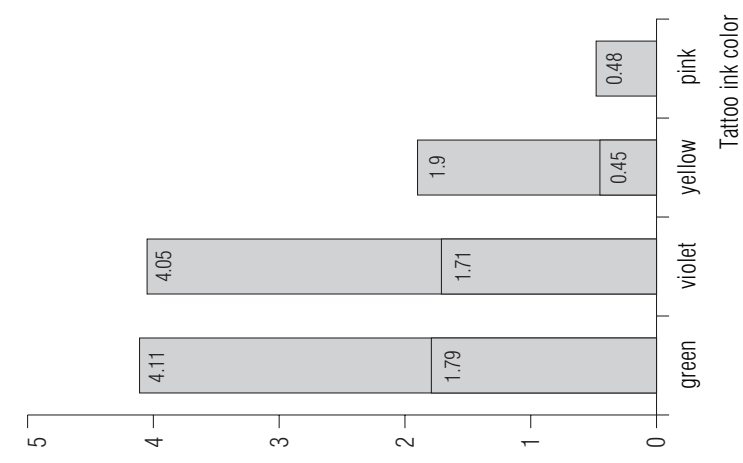

[бу/бщ] ио!ฺедиәэиоว

ఠ

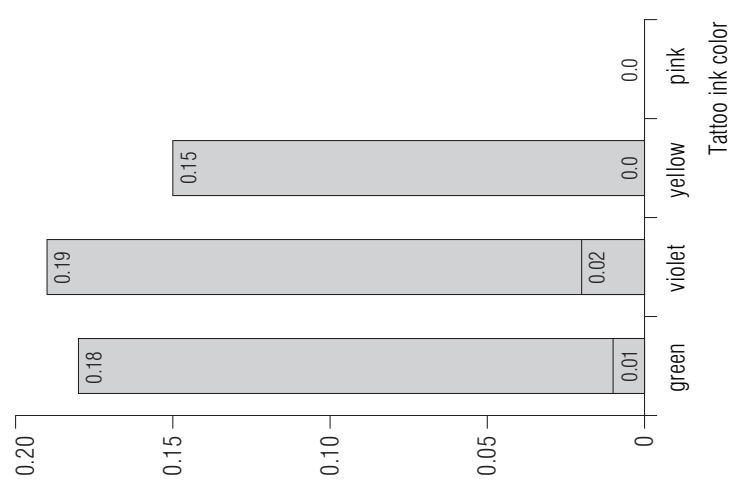

[бу/бш] ио!ฺедиәэиоว

o

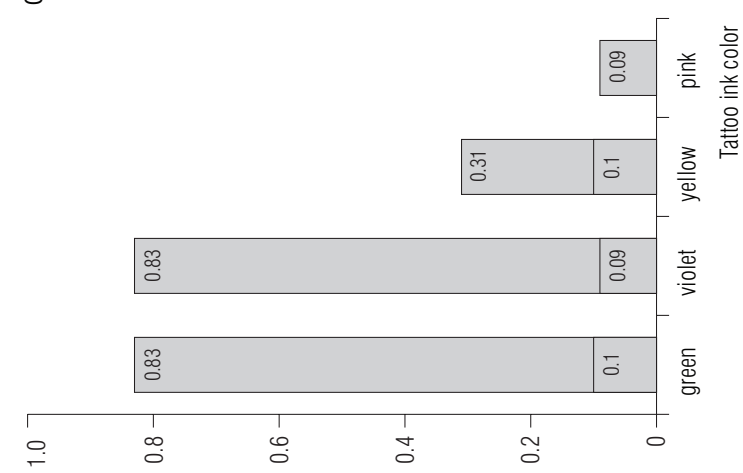

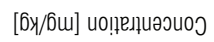

อ

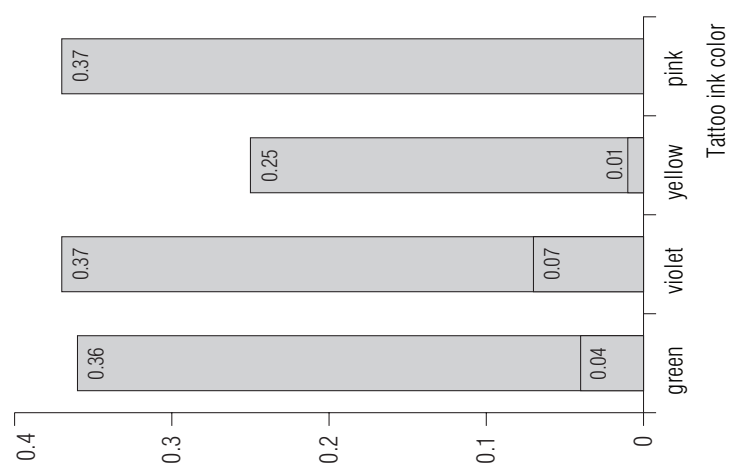

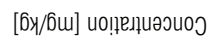

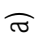

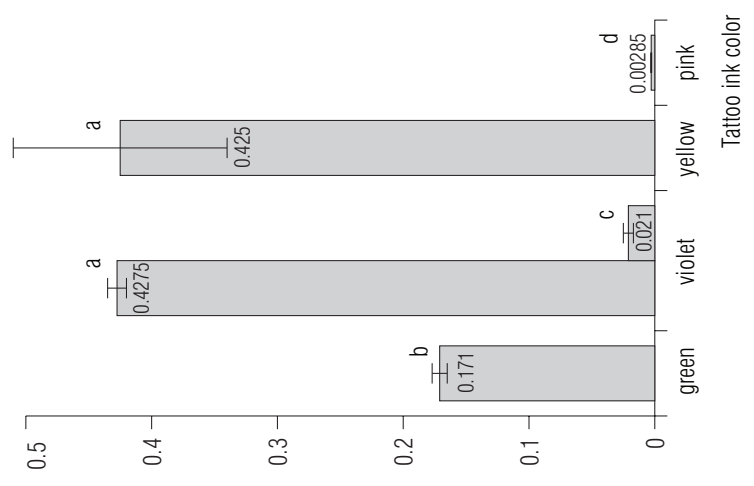

[бу/бщ] ио!ฺедиәэиоว

들

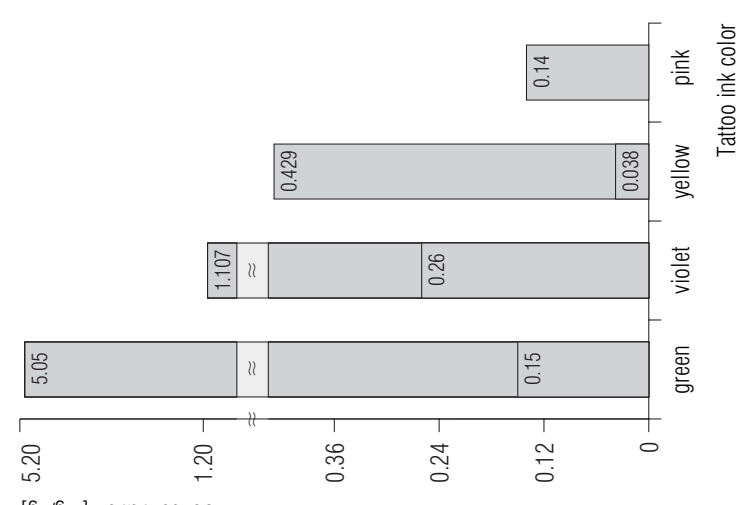

[Бу/Бш] ио!!едиәэиоว

कิ

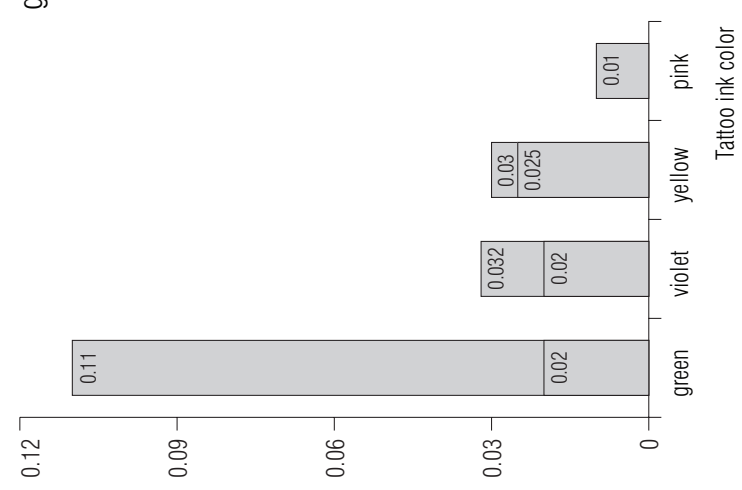

[бу/беш] ио!ฺещиәэиоว

$\simeq$

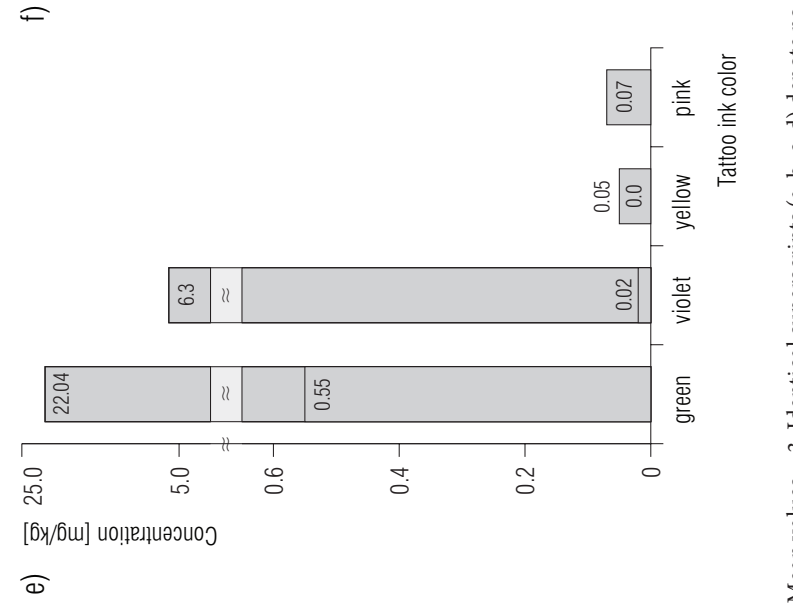


ulations, scientists have a responsibility to investigate the potential risks associated with tattooing. The analytical data presented in the paper may constitute the basis for determining the acceptable limits of the toxic $\mathrm{Tl}$ content in tattoo inks.

\section{ACKNOWLEDGMENTS}

The authors are grateful to L. Lawniczak for assistance during the preparation of the manuscript.

\section{REFERENCES}

1. Eghbali K, Mousavi Z, Ziarati P. Determination of Heavy Metals in Tattoo Ink. Bio Sci Biotechnol Res Asia. 2014;11 (2):941-6, https://doi.org/10.13005/bbra/1363.

2. Serup J, Harrit N, Linnet JT, Møhl B, Olsen O, Westh H. Tattoos - health, risks and culture with an introduction to the "seamless prevention" strategy (report). Copenhagen: The Council on Health and Disease Prevention (Vidensråd for forebyggelse); 2015. p. 1-178.

3. Mangas C, Fernandez-Figueras MT, Carrascosa JM, Soria $\mathrm{X}$, Paradelo $\mathrm{C}$, Ferrandiz C. Tattoo reaction in a sentinel lymph node from a patient with melanoma. Dermatol Surg. 2007;33:766-7, https://doi.org/j.1524-4725.2007.33161.x.

4. Hogsberg T, Loeschner K, Löf D, Serup J. Tattoo inks in general usage contain nanoparticles. Br J Dermatol. 2011;165(6): 1210-8, https://doi.org/10.1111/j.1365-2133.2011.10561.x.

5. Serup J, Bäumler W, editors. Diagnosis and Therapy of Tattoo Complications. With Atlas of Illustrative Cases. Curr Probl Dermatol. 2017;52:1-17, https://doi.org/10.1159/000453379.

6. Kaur RR, Kirby W, Maibach H. Cutaneous allergic reactions to tattoo ink. J Cosmet Dermatol. 2009;8:295-300, https:// doi.org/10.1111/j.1473-2165.2009.00469.x.

7. Groesslova Z, Vanek A, Mihaljevic M, Ettler V, Hojdovác M, Zádorováa $\mathrm{T}$, et al. Bioaccumulation of thallium in a neutral soil as affected by solid-phase association. J Geochem Explor. 2015;159:208-12, https://doi.org/10.1016/j.gexplo. 2015.09.009.

8. Wojtkowiak T, Karbowska B, Zembrzuski W, Siepak M, Lukaszewski Z. Miocene colored waters: a new significant source of thallium in the environment. J Geochem Explor. 2016;161:42-8, https://doi.org/10.1016/j.gexplo.2015.09.014.

9. Kazantzis G. Thallium in the environment and health effects. Environ Geochem Health. 2000;22(4):275-80, https://doi. org/10.1023/A:1006791514080.
10. Masa J, Helena G, Dominic V, Metka S, Domen L. Fractionation of metal contaminated garden soil after remediation. Environ Pollut. 2013;174:63-70.

11. Yashim ZI. Determination of heavy metals in black tattoo ink sold within Zaria, Nigeria. FUW Trends Sci Technol J. 2017;2(1A):122-5.

12. Karbowska B, Zembrzuski W. Fractionation and mobility of thallium in volcanic ashes after eruption of Eyjafjallajökull (2010) in Iceland. B Environ Contam Tox. 2016;97:37-43, https://doi.org/10.1007/s00128-016-1831-6.

13. Karbowska B, Rebis T, Milczarek G. Mercury-modified Lignosulfonate-stabilized Gold Nanoparticles as an Alternative Material for Anodic Stripping Voltammetry of Thallium. Electroanal. 2017;29(9):2090-7, https://doi.org/10.10 02/elan.201700090.

14. Lukaszewski Z, Jakubowska M, Zembrzuski W, Karbowska B, Pasieczna A. Flow-injection differential-pulse anodic stripping voltammetry as a tool for thallium monitoring in the environment. Electroanal. 2010; 22(17-18):1963-6, https://doi.org/10.1002/elan.201000151.

15. Peter ALJ, Viraraghavan T. Thallium: a review of public health and environmental concerns. Environ Int. 2005;31 (4):493-501, https://doi.org/10.1016/j.envint.2004.09.003.

16. Xiao T, Guha J, Boyle D, Liu C-Q, Zheng B, Wilson GC, et al. Naturally occurring thallium: a hidden geoenvironmental health hazard? Environ Int. 2004;30(4):501-7, https:// doi.org/10.1016/j.envint.2003.10.004.

17. Kabata Pendias A, Pendias H. Trace elements in soils and plants. 2. Boca Raton: CRC Press Taylor \& Francis Group; 1992, https://doi.org/10.1201/b10158.

18. United States Environmental Protection Agency (USEPA) [Internet]. Washington: The Organization; 2015 [cited 2019 Sep 1]. Regulation development for drinking water contaminants. Available from: http://www.epa.gov/safewater.zendesk.com/hc/en-us/section/202346197-Thallium.

19. Forte G, Petrucci F, Cristaudo A, Bocca B. Market survey on toxic metals contained in tattoo inks. Sci Total Environ. 2009;407:5997-6002, https://doi.org/ 10.1016/j.scitotenv.2009.08.034.

20. Tighe M, Libby D, Dorn1 S, Hosmer J, Peaslee G. A Survey of Metals Found in Tattoo Inks. J Environ Prot (JEP). 2017; 8(11):1243-53, https://doi.org/10.4236/jep.2017.811077.

21. Jacobsen E, Pedersen E, Bernth N, Serup J, Nielsen E. Chemical Substances in Tattoo Ink. København: Miljøstyrelsen; 2012.

This work is available in Open Access model and licensed under a Creative Commons Attribution-NonCommercial 3.0 Poland License - http://creativecommons.org/licenses/by-nc/3.0/pl/deed.en. 